\title{
E-COMMERCE AS A DEVELOPMENT FACTOR IN INTERNATIONAL TRADE
}

\author{
Oksana E. Kim \\ South Russia Institute of Management, Russia Presidential Academy of National Economics and Public \\ Administration, Rostov-on-Don, Russia
}

The article discusses the theoretical aspects of electronic commerce as a factor in the development of international trade. To this end, the role of advanced information technologies overall and the Internet technologies in particular in trade has been considered. The analysis of the state of electronic commerce in the world has been carried out and the place of electronic commerce in international trade has been determined. The impact of the coronavirus pandemic on e-commerce has been determined. The volumes, dynamics and trends in further development of electronic commerce in international trade at the present stage have been studied.

Keywords: e-commerce; Internet technologies; e-entrepreneurship; mobile technologies; online commerce.

\section{Introduction}

The most important trend in today's world economy is the development of electronic, or Internet, or online commerce. According to Rosstat, the share of e-commerce in the total volume of retail sales is $1.1 \%$, and according to BCG it is around $3.3 \%$ (Public investigations. Data Insight, 2020).

E-commerce is a relatively new sector of international trade, while shopping in online stores has become commonplace already. All developed countries, especially those leading countries in the field of information technology are actively implementing various ecommerce projects. The main foreign online trading platforms are Aliexpress, eBay, etc.

There are thousands of online stores in Russia as well. These include both major players, for example, Mvideo, and state structures, for example, the Postmarket, as well as

\section{Oksana E. Kim}

Graduate student, South Russia Institute of Management, Russia Presidential Academy of National Economics and Public Administration (URIU RANEPA), Rostov-on-Don, Russia Research interests: economic analysis; economics of innovation; digital economy.

E-mail:kimksu97@mail.ru

Research was conducted under the scientific advising of Dr. S.V. Zubarev 
several sites operating exclusively in the Internet - Wildberries, Yandex.Market, Avito and others.

\section{Purpose and objectives}

The purpose of the study is to analyze the features of electronic commerce as a factor in the development of international trade activity.

Research tasks put forward following this research objective include the following:

-to characterize the role of advanced information technologies and Internet technologies in trade;

- to provide a general description of the volume and dynamics of electronic commerce;

- to determine the place of electronic commerce within the world trade;

- to identify trends in further development of electronic commerce in the world.

\section{The main focus of the study}

Trade, both wholesale and retail, is one of the first areas of activity that has become the most actively implementing information technologies. Trends in the development of information technologies in trade are determined, on the one hand, by the development of market conditions as such, and on the other, by the development of information technologies themselves. Information technologies are the means and methods used to change data and its properties, according to the contents of a task or a problem to be solved (Mikhailov, 2021).

Internet technologies are one of the most relevant and modern means of information technology today, which are becoming more and more important every year. Internet technologies are technologies with the help of which information resources are created and maintained in the Internet computer network.

The forerunner of electronic commerce was the telegraph, through which banks conducted their operations back in the early 20th century. In the 1930s, telegraphic payments were replaced by the payments made through the improved Telex telegraph machine.

Abroad, development of electronic commerce began in the mid 1980s when commercial services began selling goods using dialogue and credit cards.

In Russia, e-commerce began to develop in 1999, with the electronic currency trading on the stock exchange and with the development of the Internet trading systems.

Today the Internet is fundamentally changing the lives of millions of people and the working methods of many enterprises, in various fields of activities. Trade is no exception. Significant opportunities of the Internet in trade are determined by the fact that the Internet is a new environment for communication, media, marketing.

Internet technologies in trade significantly increase the efficiency of trading activities as they:

- provide trading companies with the access to new markets;

- reduce costs;

- allow tracking income;

- analyze sales;

- track the movement and sale of goods (Pavlenko, 2021).

Development of Internet technologies in the field of trade is now going in the following directions primarily:

- intense development of electronic commerce; 


\section{E-COMMERCE AS A DEVELOPMENT FACTOR}

- introduction of mobile technologies into all related processes - automation of retail locations using tablets and smartphones;

- introduction of cloud technologies - remote branches are being introduced into the common information space. Thanks to cloud technologies, new opportunities for integration with the information systems of counterparties (suppliers, buyers, etc.) appear in international trade.

Current development of e-commerce can be explained by the following reasons:

- active development of information technologies in all the spheres of life, emergence of new software products and developments for trading enterprises;

- dynamism of trade development overall;

- constant growth of competition among trading enterprises. The sphere of trade (both wholesale and retail) is traditionally one of the most competitive fields of business activity;

- the need for more efficient management of business processes in trade.

Thus, electronic commerce is a direction of information technologies development in trade. The introduction of Internet technologies in the trade sphere has led to the development of e-entrepreneurship and e-commerce.

In general terms, e-entrepreneurship is all commercial activity performed and carried out on the Internet.

According to the definition given back in 2004 by the OECD, electronic commerce is any commercial transactions that are carried out by means of computer and telecommunications equipment.

Trade organizations receive important economic benefits from e-commerce, namely:

- cost savings while attract new customers at the same time;

- the size of the trading space is expanding when reaching the world's trading platforms;

- great savings on storage of goods;

- acceleration of processes and reduction of document management costs.

Thanks to e-commerce, buyers now purchase goods of the widest range and in the shortest possible time, from anywhere in the world, at the most reasonable and comparable prices.

Society as a whole receives economic benefits from e-commerce in that the standards of living of the population indirectly increase as the labor market expands due to the "remote work" model being implemented more actively and widely.

Another important area related to the development of electronic commerce is the use of mobile technologies in it. Mobile technologies, in this case, cover the whole variety of mobile devices that perform various information processes to simplify and improve the lives of millions of people. In relation to trade, mobile devices are represented by readers, tablets, smart wearable (smart watches in the first place), ultrabooks, etc.

In 2016, a huge step forward was made in the field of mobile technologies. For ecommerce, the most important thing was that two new payment systems - Samsung Pay and Apple Pay - were introduced nearly simultaneously. Mobility reduces the overall burden on staff of electronic stores, improves the quality of servicing, and all this, in turn, has positive effects on the image of trade companies as a whole.

Thus, the development of electronic commerce is an integral part of the global trends in the use of information technologies. With their successful use, such systems allow companies to gain significant competitive advantages on the online markets. 
Electronic commerce covers a wide range of business relations and is an indispensable tool in trade and procurement activities. Today, the global e-commerce market is defined by three leaders:

- USA is the pioneer in the development of e-commerce;

- The European Union is a leading region in global e-commerce;

- The Asia-Pacific region has a great potential for rapid development of e-commerce in the coming years.

From 2002 to the present days, global transactions occurring on the Internet are characterized by the fastest growth possible. From 2015 to 2020, the global volume of online trade increased from 1.5 to 3.9 trln USD, that is by $260 \%$ (Global retail sales in electronic commerce 2014-2023, 2021).

The dynamics of e-commerce in the world is visually presented in more detail in Figure 1.

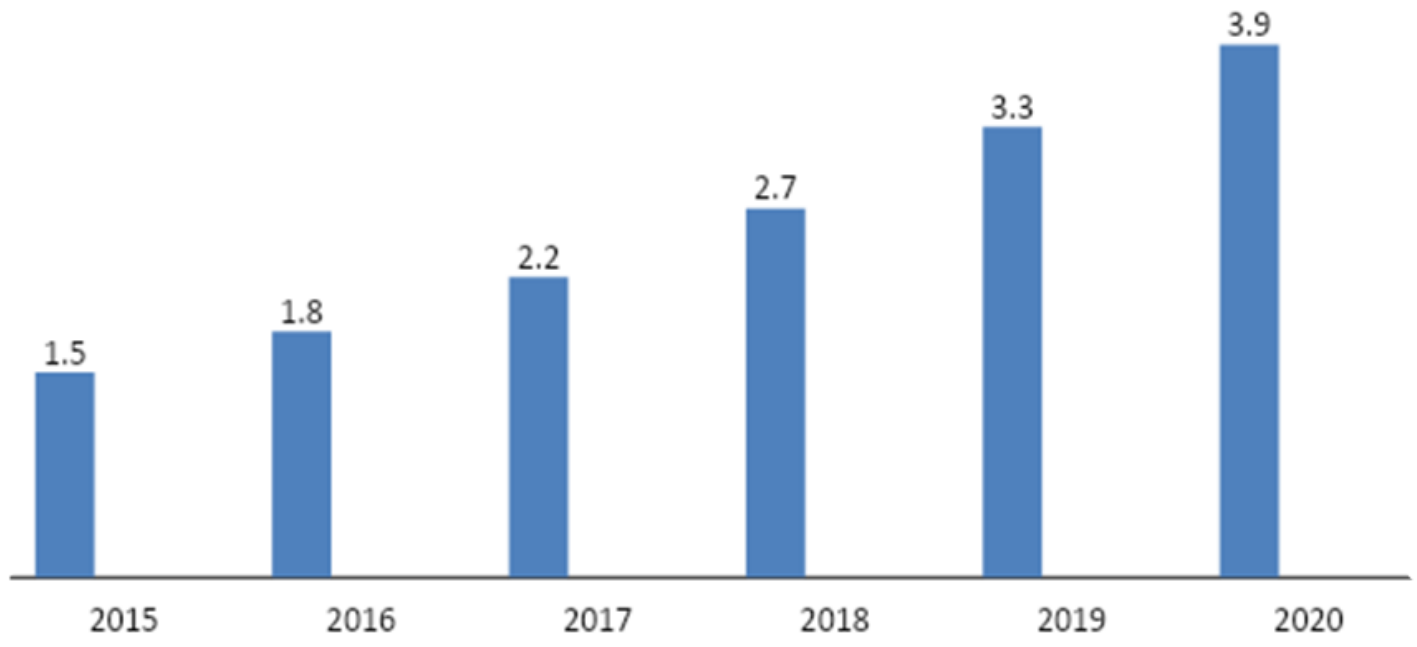

Figure 1 - Dynamics of e-commerce development, 2015 to 2020, in trln USD (Source: Global retail sales in electronic commerce 2014-2023, 2021)

The determining drivers for the online marketplace are trading platforms on the Internet, which are serving as the Internet intermediaries between sellers and buyers (Zakharov \& Chekhranova, 2020).

The largest retailers in the world today are Alibaba, Amazon, and Ebay. In 2019, Amazon began to own more than $50 \%$ of all American online commerce. In China, $30 \%$ of non-food products are bought online, and $80 \%$ of them are sold by Alibaba (Karlos, 2020).

In 2019, there were three most popular categories of goods sold online: electronics \& household appliances (the share of 23\%), clothing \& footwear (18\%), and goods for children (16\%) (Bakharev, 2020). The COVID-19 pandemic has also led to an increase in sales carried out by various online pharmacies.

The analysis of countries by the level of e-commerce development inside them as of 2020 is presented in Tab. 1. 


\section{E-COMMERCE AS A DEVELOPMENT FACTOR}

Table 1 - E-commerce development by countries, as of 2020

(Source: How did e-commerce change during 2020, and what is the consumer mood in 2021?, 2021)

\begin{tabular}{|l|c|c|c|}
\hline \multicolumn{1}{|c|}{ Countries } & $\begin{array}{c}\text { Volume of electronic } \\
\text { commerce, in bln USD }\end{array}$ & $\begin{array}{c}\text { Market growth, } \\
\text { in \% }\end{array}$ & $\begin{array}{c}\text { E-commerce volume } \\
\text { per capita, in USD }\end{array}$ \\
\hline China & 955 & 5 & 683 \\
\hline USA & 374 & 9 & 1141 \\
\hline Japan & 187 & 8 & 1479 \\
\hline UK & 133 & 13 & 1990 \\
\hline South Korea & 124 & 19 & 2393 \\
\hline Germany & 92 & 16 & 1111 \\
\hline France & 50 & 9 & 746 \\
\hline India & 44 & 29 & 32 \\
\hline Canada & 28 & 12 & 756 \\
\hline
\end{tabular}

The world leader in e-commerce is China (total volume of USD $955 \mathrm{bln}$ ). The United States are ranked the second (374 bln USD), the third place belongs to Japan (with 187 bln USD), the fourth and the fifth places are taken by Great Britain (133 bln USD) and South Korea (124 bln USD) accordingly.

Together, China and the USA share $40 \%$ of the total market. The largest Internet platform - Alibaba - belongs to China, while the most popular Internet platform in the USA is Amazon.com.

The highest market growth was shown by India $-29 \%$, and then also by South Korea (19\%) and Germany (16\%).

The share of Chinese eCommerce in the GDP of this country is $6.7 \%$. This is the highest result of all. The UK is ranked the second, with its $4.7 \%$, Germany is third, with $2.4 \%$. The fourth and the fifth place accordingly belong to the USA and India, with $1.7 \%$ and $1.5 \%$ respectively (Tab. 2 ).

Table 2 - The share of e-commerce in the GDP of the selected countries

(Source: How did e-commerce change during 2020, and what is the consumer mood in 2021?, 2021)

\begin{tabular}{|l|c|}
\hline \multicolumn{1}{|c|}{ Countries } & $\begin{array}{c}\text { The shares of e-commerce in the } \\
\text { country's GDP, in \% }\end{array}$ \\
\hline China & 6.7 \\
\hline USA & 1.7 \\
\hline UK & 4.7 \\
\hline Germany & 2.4 \\
\hline India & 1.5 \\
\hline
\end{tabular}

The share of e-commerce in the global retail trade is steadily growing. In 2015, it was $7.4 \%$, and in 2020 it was already $16.5 \%$. Thus, the growth rate has been $222.3 \%$ (Global ecommerce sales will decelarate this year, 2020). More details on e-commerce within the world trade are presented in Fig. 2. Moreover, the 2021 growth is forecasted to be at the level of $17.5 \%$. 


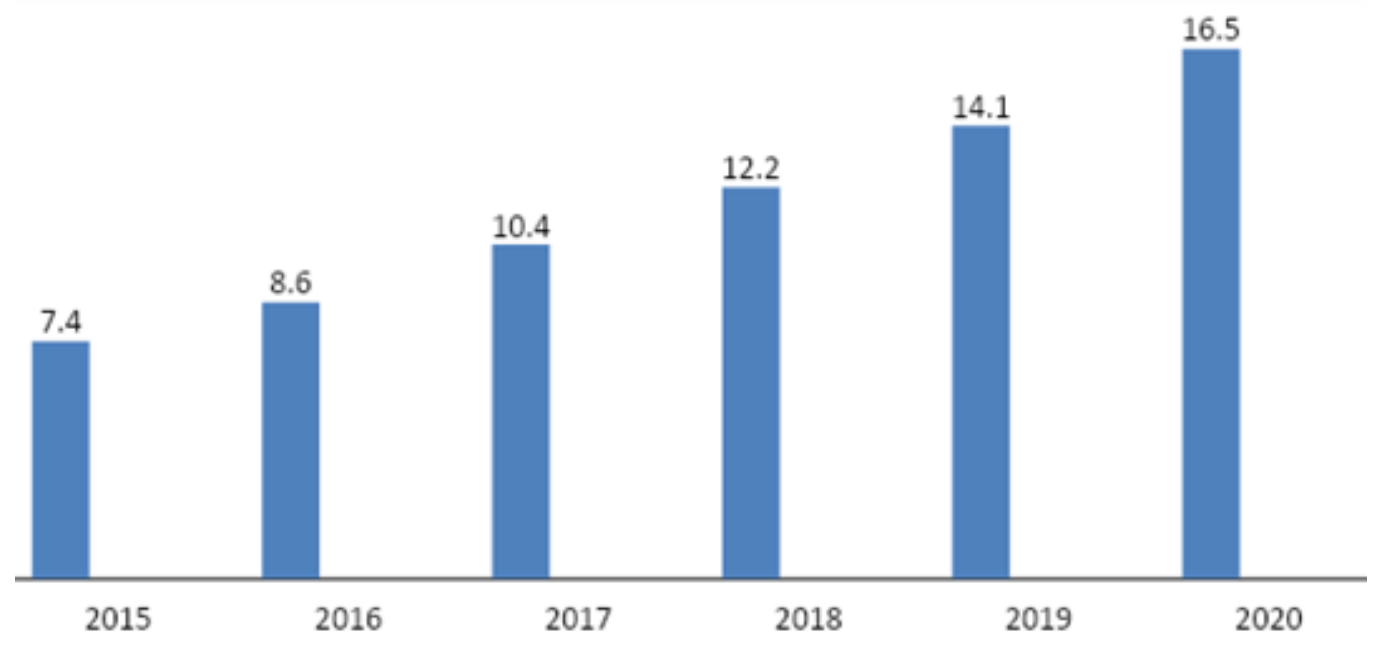

Figure 2 - The share of e-commerce in the global retail trade, in \% (Source: Global e-commerce sales will decelarate this year, 2020)

A separate issue is the development of e-commerce has been the ongoing pandemic. According to iGooods, demand at the end of March 2020 increased by 3-4 times, and the delivery time of goods to customers extended from 1-3 days to 7-10 days (Babenko, 2021). The same situation has been observed all over the world. In the USA, Amazon reported delays due to the suddenly increased volume. Prime Now and Amazon Fresh have been, for some time, unable to cope with the flow of orders and thus have reduced the guaranteed delivery speed.

According to the website www.vc.ru, by 2040, 95\% of all purchases, regardless of their type, would be made online. Thus, almost all commerce will go online, moreover, most online sales will be carried out through mobile devices. As of the end of 2020, 2.05 bln rubles were accounted for online shoppers; this is equal to $25 \%$ of the world's population. It is also expected that by the end of 2021, their number will reach 2.14 bln rubles. In 2020, $15.5 \%$ of the retail sales worldwide accounted for e-commerce (The volume of online trade in the Russian Federation in 2021 will pass the threshold of 4 trln rubbles, 2021).

The defining trend in today's e-commerce is the new set of tools that have appeared in the arsenal of sellers who have specially developed trading corporations to increase sales. These namely include:

- end-to-end delivery process by the online stores themselves;

- analytical data processing by means of the AB-testing method;

- further expansion of sales channels;

- innovative marketplace-to-marketplace trading technology for communication with popular suppliers. For example, the strategic cooperation of Yandex.Market and the largest Turkish marketplace Hepsiburada.com;

- the use of aggregator platforms, on the basis of which demand forecasting by assortment is carried out, collection of reports on sales sizes, AB tests and analysis of their results;

- partnership with major brands. For example, AliExpress has online projects with Purina and P\&G brands (Gavryushin, 2019). 


\section{E-COMMERCE AS A DEVELOPMENT FACTOR}

In general, the main trend in e-commerce is the consolidation of marketplaces of the small and mid-sized businesses. In this segment, the marketplace receives a readymade platform for its e-commerce, while spending the minimal funds on its development.

The role of e-commerce within the global economy is determined by the following features:

- thanks to the development of electronic commerce, trade transactions have become more convenient;

- small and mid-sized organizations are now able to successfully compete with large corporations;

- the system of electronic transfers (payments) is being actively developed;

- exchange of documentation is much simplified.

Online trading is gradually becoming an integral part of the global economy, it is increasingly becoming global in nature, thus, it is already quite difficult (if not impossible) to regulate it by national laws. Therefore, we can agree with the opinion that both cross-border and domestic online trade should be regulated by means of uniform legal principles (Shaidullina, 2019), developed at the international level.

As for the Russian Federation in particular, 2020 was the year of the greatest development of e-commerce in it. Key industry players quickly adapted to the conditions of the pandemic and seriously strengthened their positions. There has been explosive growth in the field of electronic commerce, and the model of consumer behavior has changed significantly.

In 2020, the growth of Russian e-commerce market was around 58\%. According to the forecasts of the head of the Ministry of Industry and Trade of Russia D. Manturov, the volume of online trade in the Russian Federation by the end of 2021 will exceed 4 trln rubles (The volume of online trade in the Russian Federation in 2021 will pass the threshold of 4 trln rubbles, 2021).

According to the MTS forecasts, by the end of 2022, the share of e-commerce in Russian retail will be around $14 \%$, and its turnover will be more than 5.5 trln rubles (Circulation of electronic commerce in Russian retail will go beyond 5.5 trln by the end of 2022, 2021). The e-commerce development scenario developed by the Data Insight research agency assumes the growth of this sphere to be 5.7 trln rubles in 2023 and then around 7.2 trln rubles in 2024 (Fig. 3).

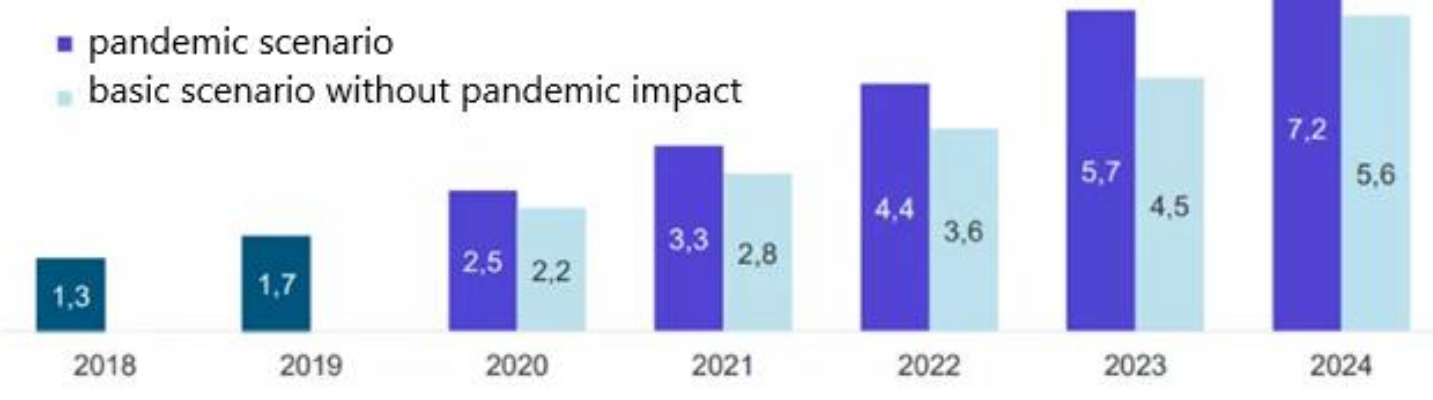

Figure 3 - Forecast of e-commerce market dynamics in Russia

(Source: Yaroshchuk, 2021) 
Russian e-commerce is developing along the way of accelerating the digital transformation of retail through robotization, automation of logistics and supply chains, artificial intelligence, AR/VR technologies for personalization and improvement of user experience.

At the same time, many Russian companies, having opened their own online stores, often fail. According to AGORA's experts, the main problems concern the desire to get a working business platform by paying the lowest price for it, while all the work on building an online store is reduced to creating a simple Internet site, and not an online business (Nushtaev, 2021).

The main problems of e-commerce development in Russia also concern imperfect logistics, poor quality of servicing, the risk of market monopolization as well as a whole group of social problems: the uncertainty of many Russians about the Internet overall, the risks of online fraud, legal restrictions on the remote sale of certain categories of goods (Reshetova, 2021).

\section{Conclusions and recommendations}

Today's popularity of online sales provides significant advantages to the global economy. E-commerce opens up new opportunities to improve the provision of services while selling goods and attracting new buyers. In the organization of electronic sales, new approaches to customers are emerging.

The analysis of the state of e-commerce within international trade has shown that the predominant share of e-commerce falls on China, the United States, and the leading economies of Europe and Asia.

As a recommendation, it is necessary to propose the development of uniform legal principles for regulating cross-border and domestic online trade. Such principles should be developed at the international level and then be recognized by all players at the national levels.

In order for Russian companies to succeed in electronic commerce, it is necessary to further develop the main elements of trade: marketing support, customer orientation, infrastructure, logistics, servicing level. Logistics should be given priority in the product life cycle.

The defining trend in the development of e-commerce as a factor of international trade is the new tools that have appeared in the arsenal of sellers who have specially developed trading corporations to increase sales volume.

\section{References}

Babenko, L. (2021). Pandemic as food for e-commerce. Available online at: https://logirus.ru/articles/interview/pandemiya_kak_pishcha_dlya_e-commerce.html [in Russian].

Bakharev, I. (2020). Internet trade in Russia 2019: Analysis of data in the outlook. Available online at: https://e-pepper.ru/news/internet-torgovlya-v-rossii-2019-analitika-data-insight.html [in Russian].

Circulation of electronic commerce in Russian retail will go beyond 5.5 trln by the end of 2022 (2021). Available online at: https://www.bfm.ru/новости/484089 [in Russian]. 


\section{E-COMMERCE AS A DEVELOPMENT FACTOR}

Gavryushin, O.Y. (2019). New directions in the development of transborder electronic trade. Russian External Economy Herald, 6, 107-117.

Global e-commerce sales will decelarate this year. eMarketer Insider Intelligence (2020). Available online at: https://www.emarketer.com/content/global-ecommerce-saleswill-decelerate-thisyear.

Global retail sales in electronic commerce 2014-2023 (2021). Available online at: https://www.statista.com/statistics/379046/worldwide-retail-e-commerce-sales

How did e-commerce change during 2020, and what is the consumer mood in 2021? (2021). Available online at: https://www.metacommerce.ru/blog/ecommerce [in Russian].

Karlos, A. (2020). Everybody's crazy about marketplaces. Market Media Analytics. Available online at: https://marketmedia.ru/media-content/marketpleysy-ot-logistov-i-bankirov [in Russian].

Mikhailov, P. (2021). Information technologies in retail trade. Available online at: http://imspm.spb.ru/articles/271655.php.

Nushtaev, D. (2021). Real problems in B2B - how are they solved in 2021. Available online at: https://www.forbes.ru/partnerskie-materialy/421343-realnye-problemy-v-b2b-kak-onireshayutsya-v-2021-godu [in Russian].

Pavlenko, A. (2021). Electronic commerce 2021: 21 indicators describing sector. Available online at: https://vc.ru/trade/200161-e-commerce-2021-21-pokazatel-harakterizuyushchiy-otrasl [in Russian].

Public investigations. Data Insight (2020). Available online at: http://www.datainsight.ru/public.

Reshetova, O. (2021). "Not only pandemic": why trade is moving online. Available online at: https://www.gazeta.ru/business/2021/04/05/13548128.shtml.

Shaidullina, V. K. (2019). Electronic trade and the prospects of its development within the world economy. University Herald, 3, 114.

The volume of online trade in the Russian Federation in 2021 will pass the threshold of 4 trln rubbles (2021). Available online at: https://www.interfax.ru/business/795862 [in Russian].

Yaroshchuk, A. (2021). Top 10 trends in e-commerce in 2021. Available online at: https://newretail.ru/business/e_commerce/top_10_trendov_e_commerce_v_2021_godu1441.

Zakharov, A.N. \& Chekhranova, T.A. (2020). Development trends in international practice of electronic trade. Russian External Economy Herald, 6, 102-106.

Paper submitted

Paper accepted for publishing

Paper published online
16 September 2021

02 December 2021

31 January 2022 